\title{
Uma verdade muito clara
}

\section{Alexandre Venzon Zanetti ${ }^{1}$}

É sempre um desafio escrever sobre um assunto que, em que pese cristalino como direito, um contexto de conveniências ou inconveniências, insiste em deturpar uma verdade vertente e que salta aos olhos.

No entanto, é dever de quem lida com saúde estar atendo às distorções que são impostas ao usuário de um sistema que é ao mesmo tempo exemplo para o mundo, garoto propaganda de governo, mas que, na prática, mata tanto os usuários sedentos por atendimento como os prestadores mal pagos e sedentos por uma remuneração digna.

A escolha por uma acomodação diferenciada não deveria passar nem perto de ser um assunto polêmico. Nenhuma das justificativas que ouvi até hoje contrárias a sua prática se sustenta. Até porque é uma verdade ou um direito tão claro que chega a beirar o ridículo sua negativa, senão vejamos.

A Constituição Federal em dois momentos inquestionáveis e de interpretação uníssona traz esse direito.

Primeiro, o $\operatorname{artigo~5^{\circ }}$ que diz: todos são iguais perante a lei, sem distinção de qualquer natureza, garantindo-se aos brasileiros e aos estrangeiros residentes no País a inviolabilidade do direito à vida, à liberdade, à igualdade, à segurança e à propriedade. Depois, temos o artigo 196 que afirma ser a saúde um direito de todos e dever do Estado, garantido mediante políticas sociais e econômicas que visem à redução do risco de doença e de outros agravos e ao acesso universal e igualitário às ações e serviços para sua promoção, proteção e recuperação.

Ora, fácil a conclusão.

Até porque todo significa um conjunto de coisas atingindo sua amplitude, ou seja: sem deixar nada de fora. Completamente, totalmente.

Dessa forma, se todos são iguais perante a lei e saúde é um direito igualmente de todos, e todos significa conjunto de coisas, plenitude sem deixar nada fora, e aqui

1 Advogado especialista em Processo Civil e Tributário, Coordenador Jurídico da Confederação Nacional da Saúde. Brasília, Brasil. E-mail: alexandre@zanetti.adv.br 
podemos dizer sem deixar ninguém fora, fica por demais evidente que qualquer um tem 0 direito de receber o atendimento de saúde que o SUS, Sistema Único de Saúde, proporciona.

Cumprido esse primeiro passo, imaginemos que um cidadão qualquer não está satisfeito com o que o SUS vem oferecendo, o que em hipótese alguma é incomum ou imoral, e resolve oferecer ao estabelecimento de saúde que o está ou vai tratá-lo, um pagamento extra, às suas expensas, sem qualquer comprometimento do erário público ou do Sistema Único, para que possa ficar em um ambiente melhor e receber conforto de uma hotelaria mais digna.

\section{Então, qual o problema?}

Recentemente, uma decisão do Supremo Tribunal Federal, válida apenas para o Município de Giruá, interior do Rio Grande do Sul, alterou a forma de atendimento prestado pelo SUS.

A decisão permite que o paciente atendido pelo SUS opte por condições especiais de internação, como quarto exclusivo ou médico de sua preferência, desde que pague a diferença em relação ao valor pago pelo Sistema Único de Saúde, a chamada 'diferenciação de classe'.

Está previsto também na decisão do Supremo que o paciente receba medicamentos e realize exames custeados pelo SUS, pagando a diferença sobre os mesmos.

Esta possibilidade altera as possibilidades dos estabelecimentos hospitalares, cria a perspectiva de um valor adicional de receita, o que pode, a longo prazo e com planejamento, trazer à relação SUS-hospital o tão sonhado equilíbrio econômicofinanceiro, sempre presente na lei e nunca na relação de fato.

Justificativas para negar esse óbvio direito do cidadão já ouvi muitas. Mas não há como se ater aos delinquentes e fraudadores para negar a aplicabilidade plena da Constituição Federal. Basta fiscalizar e disciplinar.

O que não se pode aceitar é o que alguns dizem: que a diferença de classe não é democrática. Uma bobagem do tamanho do SUS. Nessa esteira de pensamento, democrático é ser internado em macas, corredores, enfermarias lotadas e maus atendimentos, eis que, na atual democracia pregado pelo SUS e os governantes, essa é a realidade. 
Assim, esse sempre foi o entendimento emanado de nossas instituições assentada a tese no princípio constitucional que assegura o acesso universal e igualitário às ações e serviços de saúde dos cidadãos brasileiros, sendo garantido pelo Ministério da Saúde um mínimo, que é a internação em enfermarias, totalmente gratuito.

Não poderíamos discordar do entendimento no sentido de que nas situações em que o paciente ou seus familiares livremente optarem por acomodações outras que não sejam aquelas garantidas pela gratuidade do sistema. Tal opção passa a ser regulada por normas gerais que regem os contratos particulares, no Direito Civil Brasileiro, razão pela qual o preço, as condições e as demais circunstâncias que envolverem essa prestação de serviços são de estrita responsabilidade das partes contratantes.

Sempre defendemos a ideia de que inócuo é o posicionamento em sentido contrário, eis que, ao se considerar o princípio constitucional da liberdade do cidadão, inserido no artigo 5ำ caput, mediante o qual se entende pela impossibilidade de vir um ato governamental cercear tal liberdade ao se optar, livremente, por acomodações de conforto superior, quando de um internamento eletivo.

Isto é, a proibição de qualquer complementariedade restringe-se tão somente as internações em enfermarias, modelo e padrão do SUS, e quando cobertos pelo contrato de prestação de serviços que o hospital mantenha com o Sistema. Isso porque a obrigação de gratuidade é do Estado e não do prestador de serviços, que complementarmente (art. 199, $\S 1^{\circ}$, da CF) presta esses serviços, mediante contrato de direito público, com o gestor do Sistema Único de Saúde.

Como se percebe de forma clara, opção por uma acomodação diferenciada solicitada pelo paciente não pode nem deve sofrer qualquer restrição, sendo autorizada desde que seja interpretada devidamente, e não com objetivos diversos, como estimular o atendimento somente no âmbito particular, ou por imposição.

\section{Referências bibliográficas}

BRASIL. Constituição (1988). Constituição da República Federativa do Brasil. Brasília, DF: Senado, 1988. 